\title{
ESTIMATION OF RISKS OF INSURANCE COMPANIES USING INTEGRATED METHODS OF ANALYSIS
}

\author{
Nataliya Kazakova ${ }^{1}$, Margarita Melnik ${ }^{2}$ and Cholpon Nuralieva ${ }^{3}$ \\ ${ }^{1}$ Doctor of Economics, Professor, Head of Financial Research Center, Plekhanov Russian \\ University of Economics, axd_audit@mail.ru \\ ${ }^{2}$ Doctor of Economics, Professor, Department of Accounting, Analysis and Audit, Financial \\ University of the Russian Federation Government, mmargarita@fa.ru \\ ${ }^{3}$ Doctor of Economics, Professor, Department of Accounting, Analysis and Audit, Kyrgyz Russian \\ Slavic University named after the First President of Russia B.N.Yeltsin, nur-cholpon@mail.ru \\ ${ }^{*}$ Corresponding author
}

\begin{abstract}
The insurance business is subject to specific risks, for the assessment and forecasting of which requires an adapted toolkit, including a system of indicators, methods for their calculation and evaluation. For the insurance industry, a reliable scientifically based risk assessment methodology will allow to diagnose in a timely manner factors that can lead to negative consequences or unfavorable circumstances that can lead to non-fulfillment of the assumed obligations to the insured and to develop in the timeliest manner the most effective model for making managerial decisions. The methodological platform of this study was such risk analysis methods as sensitivity analysis, decision tree, scenario method, Monte Carlo method, rating evaluation. The information base of the research includes indicators of financial statements of insurance companies and credit ratings of well-known rating agencies. The result of the study is a comprehensive methodology for the integrated assessment and forecasting of risks of insurance companies, based on a system of financial indicators weighted by the probability of default, as well as non-financial indicators that take into account the company's rating and unprofitable business lines. Scientific results are tested on the example of one of the largest Russian insurance companies.
\end{abstract}

Keywords: insurance company, risk assessment, rating.

\section{INTRODUCTION}

Insurance business is an important branch of the financial market, it belongs to socially important organizations. In this regard, it has specific risks that require constant monitoring by the state and the insurance companies themselves. Popular methods of risk assessment, including sensitivity analysis, decision tree, scenario method, Monte Carlo have a set of advantages, have practical application in financial and non-financial sphere. However, it takes a lot of labor, time, attracting large amounts of external information, and in the conditions of limited resources of insurance companies do not find sufficient application. The purpose of this article is to present an adapted methodological toolkit for assessing the risks of insurance companies, which includes a system of universal financial and non-financial indicators, methods for their calculation and evaluation. The methodology provides an integral assessment of risk-tolerance and is tested on the example of one of the largest Russian insurance companies "Rosgosstrakh-Life". 


\section{DEFINITION OF MOST SIGNIFICANT RISKS OF INSURANCE COMPANIES AND INDICATORS OF THEIR ASSESSMENT}

For the insurance industry, risk assessment allows for the timely detection of conditions that may lead to negative consequences and adverse circumstances that may lead to failure to fulfill obligations to the insured [16]. Insurance companies are subject to the influence and negative impact of risks from two sides: on the one hand, they take on other people's risks, which they are transferred under various insurance and reinsurance contracts, and on the other hand, in the process of investment and other activities, the insurer has its own financial risks associated with the non-return of funds invested or inadequate profits [15].

Widely known methods of risk analysis, such as sensitivity analysis, decision tree, scenario method, Monte Carlo, undoubtedly have both certain advantages and disadvantages, which are manifested, first of all, in the high laboriousness of the assessment process, the complexity of gathering sufficient external information and because of the high cost of this analytical procedure for insurance companies [1], [2], [3]. Therefore, in practice, it is advisable to use a methodology based on taking into account the risks most significant for the industry and the specific insurance company. The methodology allows to calculate the integral indicator of resistance to risk as a weighted assessment of the specific financial and non-financial risks of the insurance company (Table 1) [5], [6], [9], [10], [11], [12].

Table 1. The most significant risks of the insurance company and the indicators of their evaluation

\begin{tabular}{|c|c|c|c|}
\hline $\begin{array}{l}\text { Risk } \\
\text { group }\end{array}$ & Types of risk & $\begin{array}{l}\text { Risk assessment } \\
\text { indicators }\end{array}$ & Sources of information or calculation \\
\hline \multirow{6}{*}{ 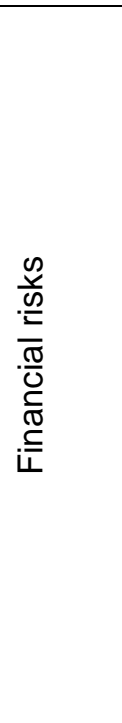 } & Credit risk & $\begin{array}{l}\text { The volume of the } \\
\text { company's investments, } \\
\text { adjusted for the } \\
\text { probability of default }\end{array}$ & $\begin{array}{l}\text { Reporting of the insurance company under } \\
\text { Form } 154\end{array}$ \\
\hline & Stock Risk & $\begin{array}{l}\text { A potential loss from the } \\
\text { company's investments } \\
\text { in the stock market }\end{array}$ & Valuation of $95 \%$ of $\mathrm{VaR}$ \\
\hline & Interest rate risk & $\begin{array}{l}\text { Balance sheet of assets } \\
\text { and liabilities }\end{array}$ & Gap-report of the company \\
\hline & $\begin{array}{l}\text { Risk of loss of } \\
\text { financial stability }\end{array}$ & Margin of solvency & $\begin{array}{l}\text { Ratio of actual and normative indicators of } \\
\text { solvency (Form 156) }\end{array}$ \\
\hline & Liquidity risk & Current liquidity ratio & $\begin{array}{l}\text { Ratio of liquid assets and liabilities of the } \\
\text { insurance company (balance sheet) }\end{array}$ \\
\hline & $\begin{array}{l}\text { Risk of } \\
\text { profitability of the } \\
\text { investment } \\
\text { portfolio }\end{array}$ & $\begin{array}{l}\text { Ratio of profitability of } \\
\text { the investment portfolio }\end{array}$ & $\begin{array}{l}\text { Ratio of profit from investment activity and } \\
\text { the amount of financial and income } \\
\text { investments in tangible assets (financial } \\
\text { statements) }\end{array}$ \\
\hline \multirow{4}{*}{ 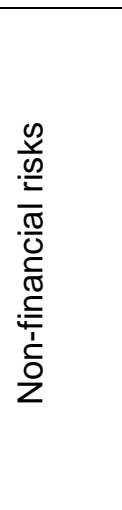 } & Operational risk & $\begin{array}{l}\text { Level of the financial } \\
\text { security system }\end{array}$ & $\begin{array}{l}\text { Availability of internal control rules for all } \\
\text { business processes, including counteraction } \\
\text { to fraudulent transactions }\end{array}$ \\
\hline & $\begin{array}{l}\text { Risk of loss of } \\
\text { business } \\
\text { reputation }\end{array}$ & Company rating & $\begin{array}{l}\text { The ratio of the company's rating in the } \\
\text { reporting and previous years }\end{array}$ \\
\hline & Insurance risk & $\begin{array}{l}\text { Loss on lines of } \\
\text { business }\end{array}$ & $\begin{array}{l}\text { The proportion of the number of lines of } \\
\text { business, loss-making of which is below the } \\
\text { planned level in the total number of lines of } \\
\text { business (accounting statements) }\end{array}$ \\
\hline & Market risk & Ratio of contract & $\begin{array}{l}\text { Ratio of the number of contracts concluded in } \\
\text { the reporting and previous years }\end{array}$ \\
\hline
\end{tabular}

\section{CALCULATION AND INTEGRATED ASSESSMENT OF RISKS OF THE INSURANCE COMPANY}

The method of integral evaluation of the most significant risks identified by the insurance company assumes the use of a score-rating method and indicators [4], [7], [8], the values of which have been translated into a 
scoresheet with subsequent calculation of the integral indicator characterizing the overall level of the risk of the insurance company.

The application of this technique will be considered on the actual indicators of the insurance company "Rosgosstrakh-Life".

Credit risk is calculated by the 154th form of reporting by insurance companies. For its calculation, the assets most exposed to credit risk are used: cash, deposits, state and municipal securities and bonds. For each type of assets, the names of credit institutions, the value of assets, as well as the credit ratings of the rating agencies that have assigned this rating (Analytical Credit Rating Agency, Rating Agency "Expert RA", Rating agency "Moody's Investors Service", Rating Agency "Fitch Ratings", Rating Agency "S \& P Global Ratings").

Credit ratings of each agency are compared with each other and each rating is assigned a probability of default of 0 to $50 \%$. After that, all the company's funds, deposits, state and municipal securities and bonds are subject to probabilities of default. Further, these probabilities are multiplied by the cost of each asset according to the accounting data and the total weighted by the probability of default for each asset type (Table 2).

Table 2. Calculation of credit risk of the company "Rosgosstrakh-Life" (2017, thousand rubles)

\begin{tabular}{|l|c|c|}
\hline Type of asset & Value of asset on balance & $\begin{array}{l}\text { The value of the asset, weighted by the } \\
\text { probability of default }\end{array}$ \\
\hline Cash & 12190669 & 467094 \\
\hline Deposits & 4584418 & 123858 \\
\hline GS & 28987622 & 76784 \\
\hline Bonds & 45306379 & 2329280 \\
\hline TOTAL & 91069088 & 2997016 \\
\hline
\end{tabular}

The total weighted on the probability of default is divided by the total value of assets on the balance sheet, thus, the total amount of investments multiplied by the probability of default is obtained $(2,997,016$ / $91,069,088=3,3 \%)$.

The stock risk is calculated using the following algorithm. Based on the values of the MB index for a specific period (from April 2008 to April 2018), then the monthly deviations of the index are calculated, after which the annual average and annual statistical deviation of the MB index value is calculated. Then we get the loss value for $95 \%$ probability (35\%). The value of shares multiplied by the amount of losses for $95 \%$ of the probability is a potential loss from investing in shares $(3,829,410$ thousand rubles $\times 0,35=1,340,294$ thousand rubles $-1,5 \%$ of the total assets considered above ). Despite the low credit and equity risks (3.3\% and $1,5 \%$, respectively, of the total volume of assets under consideration), in comparison with the company's capital, the total losses from these risks amount to $64 \%$ of the cost of capital. If the company can cover these risks and not lose out, then the level of these risks can be considered average. The total amount of losses from credit and equity risks should not exceed the company's capital. As of 31.12.2017 the company's capital is 6803364 thousand rubles, and the total amount of losses for two types of risks is 4337310 thousand rubles: 2997016 thousand rubles + 1340294 thousand rubles. Thus, in the implementation of these two risks, the company will lose most of its capital, but 2466054 thousand rubles remain unaffected.

Interest rate risk is determined through the balance sheet of assets and liabilities, which the insurance company calculates on the basis of the GAP-report (Table 3) [16].

According to this report, the company estimates two scenarios: basic and negative. The accumulated gap shows how unbalanced the company's assets and liabilities are, and also what can be the possible loss due to this imbalance [17]. According to the forecast, under the basic scenario, the company will have a positive cash flow, and under the negative scenario, it will not receive about 3,8 billion rubles in relation to the standard (tariff) margin. However, the basic scenario is used as a benchmark.

Currency risk is not included in the calculation of the integral risk of "Rosgosstrakh-Life", because of the adopted investment policy, which limits the open currency position to a maximum value of $\$ 5$ million, trying to maintain it at a level close to zero. Its daily monitoring allows you to monitor the value of assets and liabilities denominated in foreign currency and their location in the approved limit.

Risk indicators of loss of financial stability, liquidity and profitability of the investment portfolio are calculated in accordance with Table 2 on the basis of the accounting statements of the insurance company. 
Operational risk of "Rosgosstrakh-Life" is estimated as low, as it has internal regulations to counter fraudulent transactions in all business processes that minimize the losses associated with fraud in the settlement of losses [18], [19], [20].

Table 3. Report and forecast of the general level of interest rate risk for the portfolio of "Rosgosstrakh-Life"

\begin{tabular}{|c|c|c|c|c|c|c|c|c|c|c|}
\hline \multirow[b]{2}{*}{ Years } & \multicolumn{3}{|c|}{ Assets } & \multicolumn{3}{|c|}{ Liabilities } & \multirow[b]{2}{*}{ 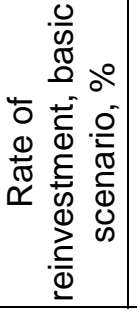 } & \multirow[b]{2}{*}{ 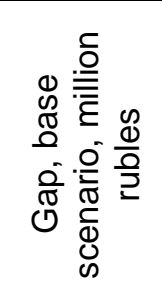 } & \multirow[b]{2}{*}{ 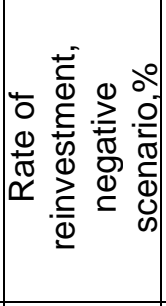 } & \multirow[b]{2}{*}{ 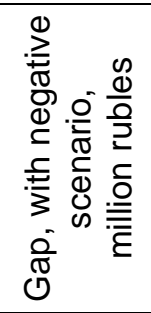 } \\
\hline & 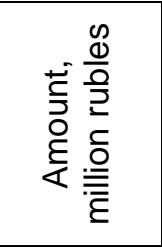 & 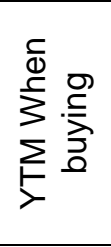 & 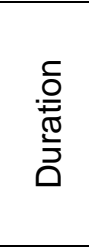 & 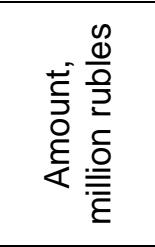 & $\begin{array}{l}\frac{0}{0} \\
\frac{\pi}{0} \\
\frac{0}{0} \\
\frac{0}{\pi} \\
\frac{0}{\frac{1}{0}} \\
\frac{0}{4}\end{array}$ & 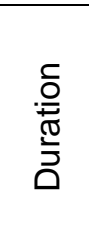 & & & & \\
\hline 2017 & 3121,2 & 10,5 & 0,2 & 488,7 & 10,8 & 0,2 & 7,60 & 2646,1 & 5,80 & 2642,8 \\
\hline 2018 & 6762,1 & 11,6 & 0,9 & 5669,3 & 13,4 & 1,0 & 7,24 & 4049,8 & 5,44 & 3547,9 \\
\hline 2019 & 13336,2 & 10,3 & 1,9 & 21536,3 & 10,3 & 2,0 & 6,99 & $-4013,8$ & 5,19 & $-5413,3$ \\
\hline 2020 & 9382,4 & 9,5 & 2,8 & 19852,9 & 9,7 & 2,7 & 6,85 & $-15347,7$ & 5,05 & $-17510,9$ \\
\hline 2021 & 7603,2 & 10,2 & 3,8 & 3220,4 & 9,5 & 4,0 & 6,74 & $-11868,2$ & 4,94 & $-14843,9$ \\
\hline 2022 & 14106,4 & 9,9 & 4,9 & 5791,8 & 9,0 & 4,7 & 6,72 & $-4309,5$ & 4,92 & $-8168,0$ \\
\hline 2023 & 1943,2 & 10,3 & 5,7 & 395,9 & 10,3 & 5,8 & 6,62 & $-2993,8$ & 4,82 & $-7174,3$ \\
\hline 2024 & 3810,8 & 10,1 & 6,8 & 112,8 & 8,7 & 6,8 & 6,49 & 620,0 & 4,69 & $-3787,9$ \\
\hline Total & 60065,3 & 10,21 & 3,04 & 57068,1 & 10,21 & 2,46 & 6,88 & 620,0 & 5,05 & $-3787,9$ \\
\hline
\end{tabular}

The risk of loss of business reputation is determined on the basis that the company's rating is kept at a high level, it is one of the leaders of the life insurance market: in 2016-2017 according to RAEX rating the company takes the second place in terms of the number of insurance premiums and insurance payments.

Insurance risk is determined on the basis of a loss-of-business report, where "Rosgosstrakh-Life" indicates four main lines of business: life insurance, credit borrowers, corporate business, accident insurance. According to quarterly data for 2016-2017 there is a decrease in loss ratio across all lines of business and in the portfolio as a whole (Table 4).

Table 4. Dynamics of unprofitability for all business lines by quarters for $\mathbf{2 0 1 6 - 2 0 1 7 , \%}$

\begin{tabular}{|c|c|c|c|c|c|c|c|}
\hline $\begin{array}{l}2016 \_1 \\
\text { quarter }\end{array}$ & $\begin{array}{c}2016 \_2 \\
\text { quarter }\end{array}$ & $\begin{array}{c}2016 \_3 \\
\text { quarter }\end{array}$ & $\begin{array}{c}2016 \_4 \\
\text { quarter }\end{array}$ & $\begin{array}{c}2017 \_1 \\
\text { quarter }\end{array}$ & $\begin{array}{c}2017 \_2 \\
\text { quarter }\end{array}$ & $\begin{array}{c}2017 \_3 \\
\text { quarter }\end{array}$ & $\begin{array}{c}2017 \_4 \\
\text { quarter }\end{array}$ \\
\hline 35 & 33 & 34 & 29 & 27 & 27 & 27 & 27 \\
\hline
\end{tabular}

Market risk, calculated on the basis of an assessment of the dynamics of the number of contracts concluded (the contracting ratio is 1,001 ), is at a low level.

Table 5 presents the procedure for the integrated risk assessment of the insurance company "RosgosstrakhLife".

Thus, it can be concluded that the credit risk of the insurance company, that is, the risk of non-return or delay in payment (due to a decrease in the creditworthiness of the borrower or a deterioration in the business reputation of the borrower) is at an average level. The stock risk is also at the middle level. In order to minimize this risk, the company needs to increase the efficiency of its investment activities and diversify its securities portfolio. Possible losses from the implementation of credit and fund risks amount to 5074341 thousand rubles. The company's capital is sufficient to cover these risks and not to lose money. The company's assets and liabilities are fairly balanced. The losses of the company due to changes in foreign exchange rates are minimal. The actual size of the solvency margin exceeds the normative by $25 \%$. Risks of loss of financial stability, liquidity and profitability of the investment portfolio are at a low level. The company is liquid, as the current liquidity ratio reaches 0,88 at a standard value of 0,5 . The investment activity of the company is profitable (the return on the investment portfolio is $8,8 \%$ with a normative value of $2 \%$ ). 
The operational risk of the company is low. The company conducts an active policy to combat fraud in settling losses, developed a regulation to counter fraudulent transactions, as well as internal control of all business processes. Insurance risk of the company is at a low level: unprofitability across all lines of business is below the planned values, which indicates that the company is financially stable and competitive.

The company is one of the market leaders and for many years has been among the top three life insurance companies in Russia. The actual unprofitability of the company is lower than planned, which, of course, is a positive aspect. The number of concluded insurance contracts in 2017 is higher than in 2016. This fact shows that the company does not lose its target audience and continues to attract new customers.

Table 5. Calculation of the integral assessment of the risks of the insurance company "Rosgosstrakh-Life"

\begin{tabular}{|c|c|c|c|c|c|c|}
\hline $\begin{array}{l}\text { Risk } \\
\text { group }\end{array}$ & $\begin{array}{l}\text { Types of } \\
\text { risk }\end{array}$ & $\begin{array}{c}\text { Risk } \\
\text { assessment } \\
\text { indicators }\end{array}$ & $\begin{array}{c}\text { Value } \\
\text { of Risk, } \\
\%\end{array}$ & Risk assessment criteria in points & $\begin{array}{c}\text { Scor } \\
\mathrm{e}\end{array}$ & $\begin{array}{l}\text { The } \\
\text { level of } \\
\text { risk }\end{array}$ \\
\hline \multirow{6}{*}{ 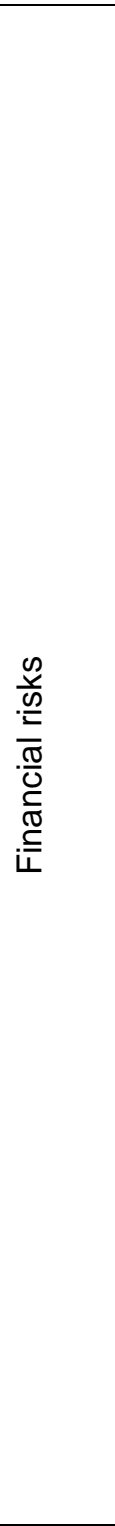 } & Credit risk & $\begin{array}{l}\text { The volume } \\
\text { of the } \\
\text { company's } \\
\text { investments } \\
\text {, adjusted } \\
\text { for the } \\
\text { probability } \\
\text { of default }\end{array}$ & $3,3 \%$ & $\begin{array}{l}\text { Low - } 3 \text { points - total losses from credit } \\
\text { and equity risks are covered by the } \\
\text { company's capital (need }<50 \% \text { of } \\
\text { capital) } \\
\text { Average - } 2 \text { points - total losses from } \\
\text { credit and equity risks are covered by } \\
\text { the company's capital (it is necessary }> \\
50 \% \text { of the capital) } \\
\text { High - } 1 \text { point - total losses from credit } \\
\text { and stock risks are greater than the } \\
\text { company's capital }\end{array}$ & 2 & Average \\
\hline & Stock Risk & $\begin{array}{l}\text { A potential } \\
\text { loss from } \\
\text { the } \\
\text { company's } \\
\text { investments } \\
\text { in the stock } \\
\text { market }\end{array}$ & $1,5 \%$ & $\begin{array}{l}\text { Low - } 3 \text { points - total losses from credit } \\
\text { and equity risks are covered by the } \\
\text { company's capital (need }<50 \% \text { of } \\
\text { capital) } \\
\text { Average - } 2 \text { points - total losses from } \\
\text { credit and equity risks are covered by } \\
\text { the company's capital (it is necessary }> \\
50 \% \text { of the capital) } \\
\text { High - } 1 \text { point - total losses from credit } \\
\text { and stock risks are greater than the } \\
\text { company's capital }\end{array}$ & 2 & Average \\
\hline & $\begin{array}{l}\text { Interest } \\
\text { rate risk }\end{array}$ & $\begin{array}{l}\text { Balance } \\
\text { sheet of } \\
\text { assets and } \\
\text { liabilities }\end{array}$ & - & $\begin{array}{l}\text { Low - } 3 \text { points - a positive gap in both } \\
\text { scenarios } \\
\text { Average - } 2 \text { points - a positive gap in } \\
\text { one scenario } \\
\text { High - } 1 \text { point - a negative gap }\end{array}$ & 2 & Average \\
\hline & $\begin{array}{l}\text { Risk of } \\
\text { loss of } \\
\text { financial } \\
\text { stability }\end{array}$ & $\begin{array}{l}\text { Margin of } \\
\text { solvency }\end{array}$ & 1,25 & $\begin{array}{l}\text { Low - } 3 \text { points - Indicator } 1 \\
\text { Average }-2 \text { points - the indicator is } \\
\text { equal to } 1 \\
\text { High }-1 \text { point - the indicator }<1\end{array}$ & 3 & Low \\
\hline & $\begin{array}{l}\text { Liquidity } \\
\text { risk }\end{array}$ & $\begin{array}{l}\text { Current } \\
\text { liquidity } \\
\text { ratio }\end{array}$ & 0,88 & $\begin{array}{l}\text { Low - } 3 \text { points - rate }>0.5 \\
\text { Average }-2 \text { points - the indicator is } \\
0.5 \\
\text { High - } 1 \text { point - the indicator is below } \\
0.5\end{array}$ & 3 & Low \\
\hline & $\begin{array}{l}\text { Risk of } \\
\text { profitability } \\
\text { of the } \\
\text { investment } \\
\text { portfolio }\end{array}$ & $\begin{array}{l}\text { Ratio of } \\
\text { profitability } \\
\text { of the } \\
\text { investment } \\
\text { portfolio }\end{array}$ & $8,8 \%$ & $\begin{array}{l}\text { Low - } 3 \text { points-Indicator }>2 \% \\
\text { Average }-2 \text { points - the indicator is } \\
\text { equal to } 2 \% \\
\text { High - } 1 \text { point - the indicator is below } \\
2 \%\end{array}$ & 3 & Low \\
\hline \multirow{2}{*}{ 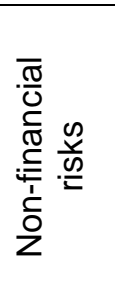 } & $\begin{array}{l}\text { Operation } \\
\text { al risk }\end{array}$ & $\begin{array}{l}\text { Level of the } \\
\text { financial } \\
\text { security } \\
\text { system }\end{array}$ & Yes & $\begin{array}{l}\text { Low - } 3 \text { points - presence of current } \\
\text { regulations } \\
\text { Average }-2 \text { points - regulations under } \\
\text { development } \\
\text { High }-1 \text { point - lack of regulations }\end{array}$ & 3 & Low \\
\hline & $\begin{array}{l}\text { Risk of } \\
\text { loss of } \\
\text { business }\end{array}$ & $\begin{array}{l}\text { Company } \\
\text { rating }\end{array}$ & 1 & $\begin{array}{l}\text { Low - } 3 \text { points - positive dynamics } \\
\text { Average }-2 \text { points - stagnation } \\
\text { High }-1 \text { point - decrease }\end{array}$ & 2 & Average \\
\hline
\end{tabular}


IJASOS- International E-Journal of Advances in Social Sciences, Vol. IV, Issue 12, December 2018

\begin{tabular}{|c|c|c|c|c|c|}
\hline reputation & & & & & \\
\hline $\begin{array}{c}\text { Insurance } \\
\text { risk }\end{array}$ & $\begin{array}{l}\text { Loss on } \\
\text { lines of } \\
\text { business }\end{array}$ & 4 from 4 & $\begin{array}{l}3 \text { - all lines of business have a loss } \\
\text { ratio below the planned one } \\
2 \text { - three - two lines of business have a } \\
\text { loss ratio below the planned } \\
1 \text { - one, no line of business has a loss } \\
\text { ratio below the planned }\end{array}$ & 3 & Low \\
\hline Market risk & $\begin{array}{l}\text { Ratio of } \\
\text { contract }\end{array}$ & 1,001 & $\begin{array}{l}\text { Low - } 3 \text { points - positive dynamics } \\
\text { Average - } 2 \text { points - stagnation } \\
\text { High - } 1 \text { point - decrease }\end{array}$ & 3 & Low \\
\hline \multicolumn{5}{|c|}{ Cumulative risk tolerance assessment - 26} & Low \\
\hline
\end{tabular}

As a result of the calculations, an integral risk assessment was obtained, equal to 26 points out of 30 admissible, that is, the insurance company "Rosgosstrakh-Life" is a risk-based.

\section{CONCLUSIONS}

The result of the research is the methodology of integral risk assessment of insurance companies, using a system of financial indicators calculated on the basis of financial statements and non-financial indicators that take into account business reputation (credit ratings of well-known rating agencies), unprofitable business lines and market risk. The proposed toolkit makes it possible to reduce the laboriousness of risk assessment, reduce time and resources for collecting and preparing information, thereby optimizing the cost of the risk assessment procedure for insurance companies [5], [6]. Approbation of this technique on the example of one of the largest Russian insurance companies showed the expediency of using the selected indicators from the position of accounting for the risks most significant for the industry and the specific insurance company. Scientific results can find perspective application in the whole system of the insurance market, in the audit business and consulting [13], [14].

\section{REFERENCE LIST}

Benish, M. (1999). The detection of earnings manipulation. Financial analysis journal. September.

Ekimova, K., Bolvachev ,A., Dokhoyan ,Z., Danko, T., Zarova, E., Shemetkova, O., \& Sekerin V.(2016). Improvement of the methods for assessing the value of diversified companies in view of modification of the herfindahl-hirschman model. Journal of Internet Banking and Commerce. T.

21. No. SPEC.ISSUE 4.

Ekimova, K., \& Frumina, S. (2016). Economic practicability substantiation of financial instrument choice. Journal of Applied Economic Sciences. T. 11. No.8. Pp. 1613-1623.

Kazak, A.,\& Slepukhina, Yu. (2010) Financial Risks in the Insurance Business: Models and Methods of Evaluation. Izvestiya Ural State University. No.2 (77). Pp. 75-89.

Kazakova, N., (2003). Information-analytical system as a modern tool of economic analysis. Statistical issues. No. 10. Pp. 32-42.

Kazakova ,N. (2017). Analytical procedures: experience of use in auditing and assessment of economic activity. Bulletin of the Financial University. No.2. Pp.113-120.

Kazakova N., Gendon L., \& Khlevnaya, E. (2016). Development potential of Russian mining-and-chemical holdings. GORNYI ZHURNAL. No. 7. pp. 89-91.

Kazakova, N., Gendon, A., Khlevnaya, E., \& Sedova, N. (2017). Prediction of development in the mining and chemical industry in Russia and in the world. Gornyi Zhurnal. No. 4. pp. 49-52.

Kazakova, N., Bolvachev, A., Gendon, A., \& Golubeva, G. (2016). Monitoring Economic Security in the Region Based on Indicators of Sustainable Development. Studies on Russian Economic Development. Vol. 27. No. 6. pp. 650-660.

Kazakova, N., Bolvachev, A., Gendon, A., \& Golubeva, G. (2017). Value Added Analysis and Trend 
Forecasting in the Manufacturing Industry in Kaliningrad Oblast. Studies on Russian Economic Development. Vol. 28. No. 2. Pp. 160-168.

Kaplan, R., \& Norton D. (1992). The Balance Score Card - Measures that drive performance, in: Harvard Business Review, Jan-Feb 1992. Pp. 71-79.

Kaplan, R., \& Norton, D. (1997). Balanced Scorecard: Strategien erfolgreich umsetzen, Stuttgart . P. 333.

Karagod, V., Golubeva, N., \& Erokhina E. (2017). Institute of Audit in Russia: Challenges and perspectives. Journal of Advanced Research in Law and Economics. Vol. 8, Issue 1. Pp. 330-339.

Karagod, V., Golubeva, N., \& Erokhina, E. (2018). The zones of turbulence in the Russian audit market. Abstracts \& Proceedings of INTCESS 2018. 5th International Conference on Education and Social Sciences. No.1. Pp.1102-1105.

Labusheva, J. (2015). Evaluation of the risks of the insurance company for making managerial decisions. P. 167.

Review of key performance indicators of insurers. Information-analytical materials (2017). https://www.cbr.ru/finmarkets/files/supervision/review_insure_17Q4.pdf - Central Bank of the Russian Federation.

Ukolov, A. (2014). Risk management of an insurance organization. P. 467.

Wells, J. (2010) Handbook on preventing and detecting corporate fraud. P. 672.

Wells, J. (2009) Corporate fraud. Lessons the negative side of the business. P. 624.

Wells, J. (2008) Handbook on preventing and detecting corporate fraud. P. 80. 